\title{
Locally Advanced Carcinoma
}

National Cancer Institute

\section{Source}

National Cancer Institute. Locally Advanced Carcinoma. NCI Thesaurus. Code C148130.

A carcinoma that has spread from its orig inal site of growth to nearby tissues or lymph nodes. 